\title{
ポリ（エチレンテレフタレート）䋊維のゾーン延伸における 延伸温度と臨界ネッキング応力との関係
}

\author{
鈴木 章泰*1 ・ 小林警子*1 ・功刀 利夫*1
}

(受付 1993 年 4 月 8 日・蕃查終了1 1993 年 5 月 31 日)

\begin{abstract}
要 旨 ポリ(エチレンテレフタレート)織維のネッキングゾーン延伸における臨界ネッキング於力 $\left(\sigma_{\mathrm{c}}\right)$ と延伸 温度 $\left(T_{\mathrm{d}}\right)$ との間には, ガラス転移温度 $\left(T_{\mathrm{g}}=75^{\circ} \mathrm{C}\right)$ 以下でほぼ直線関係が成立することが確認された。 また，この 温度域では, $\sigma_{\mathrm{c}}$ と $\left(T_{\mathrm{g}}-T_{\mathrm{d}}\right)$ との間に次式で示されるような簡単な実験式を得た。 $\sigma_{\mathrm{c}}=C\left(T_{\mathrm{g}}-T_{\mathrm{d}}\right)$. なお， この定数 $C$ は $0.546 \mathrm{MPa} \cdot{ }^{\circ} \mathrm{C}^{-1}$ であった。 $\sigma_{\mathrm{c}}$ で延伸した織維のネッキング延伸倍率は 3 倍から 5 倍の範用内にあり、 $T_{\mathrm{d}}$ か高い ほど延伸倍率は大きくなる傾向にある。一方，複屈折は $T_{\mathrm{d}}$ の低下とともにほほ直線的に增加し， $T_{\mathrm{d}}=102^{\circ} \mathrm{C}$ で延伸

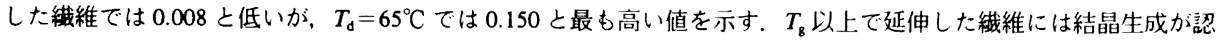
められないか， $T_{\mathrm{g}}$ 以下の延伸では配向結晶化により微結晶が生成している。また， $T_{\mathrm{d}}$ が低いまど結晶化度及ひ結晶 配向性が高いこ之か，広角 $\mathrm{X}$ 線回折写真から確認された。. $T_{8}$ 以下で延伸した瀻維の動的弾性率一温度曲線には皮革 状領域か存在するか， $T_{\mathrm{g}}$ 以上で延伸した紻維ではこの領域が存在しない，また， $T_{\mathrm{d}}=65^{\circ} \mathrm{C}$ で延伸した織維の $20^{\circ} \mathrm{C}$ における動的弾性率は $6.8 \mathrm{GPa}$ と最む高く， $T_{\mathrm{d}}$ が高くなると順次低下し， $T_{\mathrm{d}}=94^{\circ} \mathrm{C}$ の延伸織維では $2.0 \mathrm{GPa}$ と低 い.
\end{abstract}

\section{1 緒言}

非晶性高分子の延伸過程は, 結晶性高分子の延伸過 程”のように結晶の破壊や再結晶化などの複雑な構造変 化を考慮する必要がなく，単純な塑性変形と考えること ができる．すでに著者らは，未延伸の状態で非晶質が得 られるポリエーテルエーテルケトン (PEEK) フィルム2) とポリ塩化ビニル䄉維音をネッキングゾーン延伸し, ネックが発生するために必要最少限の応力である臨界 ネッキング応力 $\left(\sigma_{\mathrm{c}}\right)$ と延伸温度 $\left(T_{\mathrm{d}}\right)$ との関係を検討し た。 その結果, これらの材料では $\sigma_{\mathrm{c}}, T_{\mathrm{d}}$ 及びガラス転移 温度 $\left(T_{\mathrm{g}}\right)$ の 3 者の間に (1) 式のような簡単な経験則が 成立することが分かった。

$$
\sigma_{\mathrm{c}}=C\left(T_{\mathrm{g}}-T_{\mathrm{d}}\right)
$$

また，この経験則は未延伸状態で非晶質が得られる高分 子であれば $T_{\mathbf{g}}$ 以下において一般に成立するものと考え た.

本研究では, (1) 式の普遍性をさらに確認するために, 未延伸状態でほぼ非晶質であるポリ（エチレンテレフ夕 レート) 緎維の臨界ネッキング応力之延伸温度の関係に ついても検討したところ，(1) 式と同様な実験式が成立 することが分かったので報告する，さらに，臨界ネッキ ング応力下で延伸した織維の延伸温度と配向結晶化との 相関についても検討した.

*1 山梨大学工学部化学生物工学科 ( 3400 甲府市武田 4-3-11)

\section{2 実験}

\section{1 試料}

試料は東レ(株)提供の未延伸ポリ（エチレンテレフ夕 レート）（以下 PET と略記する）䄉維で，直径は 248 $\mu \mathrm{m}$, 複屈折は $1 \times 10^{-4}$, 結晶化度は $4 \%$ である。 また, この原織維はほぼ無配向・非晶質であることが広角 $\mathrm{X}$ 線回折写真加も確認されている.

\section{2 ネッキングゾーン延伸}

ネッキングゾーン延伸はPEEK フィルムやポリ塩化 ビニル䄉維のゾーン延伸の場合と同様の装置を用い，加 熱炉の移動速度を $10 \mathrm{~mm} / \mathrm{min}$ とした．印加する応力は 設定した延伸温度で加熱炉内にネックが発生するために 必要な最少限の応力とし，これを臨界ネッキング応力 $\left(\sigma_{\mathrm{c}}\right)$ と定義する。ここではネッキングゾーン延伸の延伸 温度を $65^{\circ} \mathrm{C}$ から $102^{\circ} \mathrm{C}$ までの範囲とした。 $65^{\circ} \mathrm{C}$ 以下の 延伸では䄉維が白化するので $65^{\circ} \mathrm{C}$ を $T_{\mathrm{d}}$ の下限とし，ま た, $100^{\circ} \mathrm{C}$ 以上では $\sigma_{\mathrm{c}}$ が極めて小さく, 延伸温度にほ上 んど依存しないため, $102^{\circ} \mathrm{C}$ を上限温度とした。

\section{3 複屈折の測定}

Bereck 型コンペンセーターを装着したオリンパス (株)製偏光顕微鏡を用い，白色光で測定したレターデー ションから複屈折を算出した。 なおレターデーション 測定の際, 水晶単結晶から切り出した $\mathrm{X}-\mathrm{Z}$ 補償板を併 用した。 


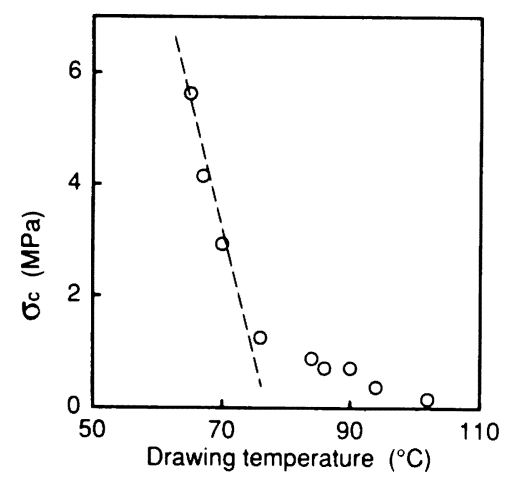

Fig. 1. Changes in the critical necking tension $\left(\sigma_{\mathrm{c}}\right)$ with drawing temperature.

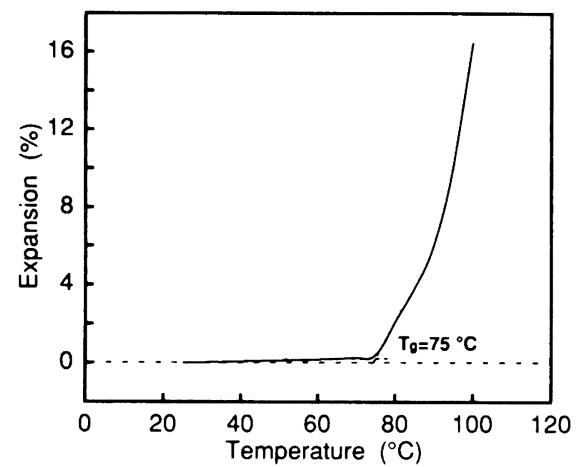

Fig. 2. TMA curve for the original fiber.

\section{4 密度测定およひ結晶化度の算出}

密度はトルエン-四塩化炭素系混合溶媒を用い， $25^{\circ} \mathrm{C}$ で浮沈法により測定した。重量分率の結晶化度 $\left(X_{\mathrm{w}}\right)$ 一

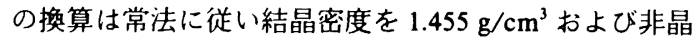
密度を $1.335 \mathrm{~g} / \mathrm{cm}^{3}$ として行った4).

\section{5 広角 $\mathrm{X}$ 線回折写真}

広角 $\mathbf{X}$ 線回折写真の撮影は(株)リガク製 $\mathbf{X}$ 線発生装 置に平板カメラを取り付けて行った，撮影には二ッヶル フィルターを通した $\mathrm{Cu}-\mathrm{K} a$ 線を用い, 試料とカメラ間 の距離は $40 \mathrm{~mm}$ ，露光時間は 2 時間とした.

\subsection{TMA 测定}

TMA 測定は(株)リガク製TAS200システムの熱応力 ひずみ測定装置(SS-TMA)を用いた。この測定では, 測定 試料長は $15 \mathrm{~mm}$, 印加する荷重は䄉維の弛緩を防ぐため の必要最小限の荷重 $(0.5 \mathrm{~g})$ とした. また測定は $5^{\circ} \mathrm{C} / \mathrm{min}$ の昇温速度で室温から約 $230^{\circ} \mathrm{C}$ までの範囲で行った。

\section{7 功的粘弾性測定}

動的粘弾性の測定は，(株)オリエンテック製 VIBRON DDV-II 型を用い, 駆動周波数 $110 \mathrm{~Hz}$ で, 室温から $215^{\circ} \mathrm{C}$ までの温度範囲にわたって, 昇温速度 $2^{\circ} \mathrm{C} / \mathrm{min}$ で 窒素気流中で行った。

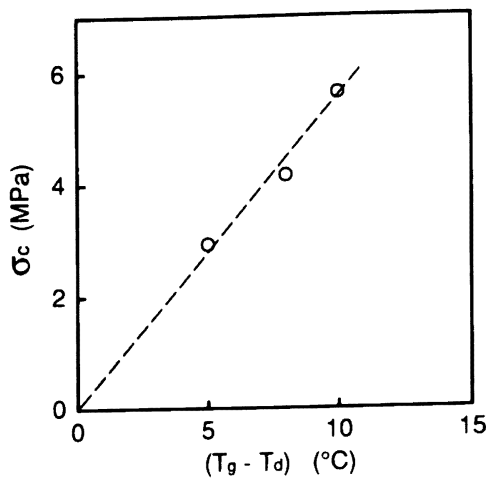

Fig. 3. Relation between the critical necking tension $\left(\sigma_{\mathrm{c}}\right)$ and $\left(T_{\mathrm{g}}-T_{\mathrm{d}}\right)$.

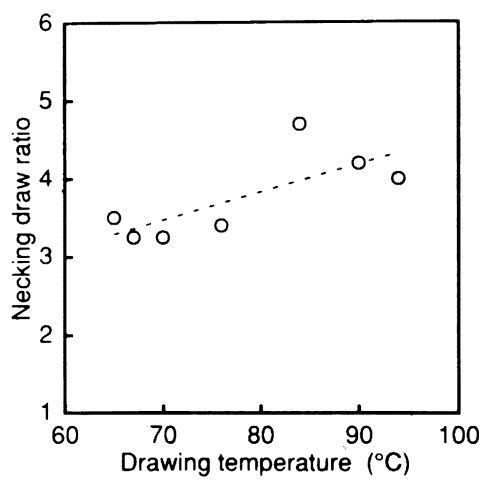

Fig. 4. Changes in the necking draw ratio with drawing temperature.

\section{3 結果および考察}

\section{1 臨界ネッキング応力と延伸温度の関係}

ネッキングゾーン延伸時における臨界ネッキング応力 $\left(\sigma_{\mathrm{c}}\right)$ と延伸温度 $\left(T_{\mathrm{d}}\right)$ との関係を Fig. 1 に示す. $T_{\mathrm{d}}=$ $80^{\circ} \mathrm{C}$ 以下の温度域では $T_{\mathrm{d}}$ の低下に伴い $\sigma_{\mathrm{c}}$ はほぼ直線 的に増加する. しかし, $T_{\mathrm{d}}=80^{\circ} \mathrm{C}$ 以上では $\sigma_{\mathrm{c}}$ の值は小さ く, $80^{\circ} \mathrm{C}$ 以下の温度域で成立した直線関係から外れる.

また, 前報の PEEK フィルム ${ }^{2}$ とポリ塩化ビニル緎 維 ${ }^{3)}$ において $\sigma_{\mathrm{c}}$ と $\left(T_{\mathrm{g}}-T_{\mathrm{d}}\right)$ との間には原点を通る直線 関係が成立したので, PET 織維についても同様のプロッ トを試みた。なお，用いた $T_{\mathrm{g}}\left(75^{\circ} \mathrm{C}\right)$ は Fig. 2 に示す原 緎維の TMA 曲線から求めた，得られた $\sigma_{\mathrm{c}}$ と $\left(T_{\mathrm{g}}-T_{\mathrm{d}}\right)$ との関係を Fig. 3 に示す. 両者の関係は原点を通る直線 で表され，(2) 式のような簡単な経験則が成立する.

$$
\sigma_{\mathrm{c}}=C\left(T_{\mathrm{g}}-T_{\mathrm{d}}\right) \quad\left(\text { ただし, } T_{\mathrm{g}}>T_{\mathrm{d}}\right)
$$

なお，この定数 $C$ は $0.546 \mathrm{MPa} \cdot{ }^{\circ} \mathrm{C}^{-1}$ であった。この值

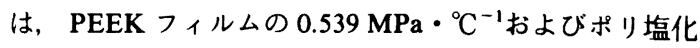
ビニル繊維の $0.947 \mathrm{MPa} ・{ }^{\circ} \mathrm{C}^{-1}$ と比較すると, PEEK の C值にかなり近い，これが，両ポリマーの化学構造の類 
ポリ（エチレンテレフタレート）紻維のゾーン延伸における延伸温度と臨界ネッキング応力との関係

似性に関連するか否かはなお検討すべき事項であるが, 非常に興味深い結果である.

3.2 臨界ネッキング応カ下で得られたソーン延伸絓 維の延伸性, 配向性, および結晶性

次に, 種々の $T_{\mathrm{d}}$ で得られた延伸繊維のネッキング延 伸倍率 $\left(\lambda_{n}\right)$ と複届折 $(\Delta n)$ をそれぞれ Fig. 4 と 5 に示 す.いずれの繊維の $\lambda_{n}$ も 3 倍から 5 倍の範囲内にあり,

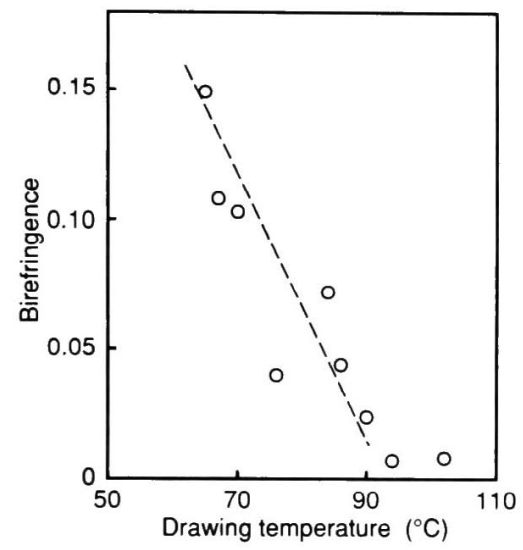

Fig. 5. Changes in the birefringence with drawing temperature.
$T_{\mathrm{d}}$ が高いほど $\lambda_{n}$ は大きい, 一方, $\Delta n$ は $T_{\mathrm{d}}$ の低下伴い ほぼ直線的に増加する。 $T_{\mathrm{d}}=65^{\circ} \mathrm{C}$ で延伸した䋐維では 0.150 之最も高く, 固有複屈折 $0.310^{5)}$ の約 $1 / 2$ に相当す る. しかし， $T_{\mathrm{d}}=102^{\circ} \mathrm{C}$ で延伸した䄉維の $\Delta n$ は 0.008 上 極めて低く，ほとんど無配向状態である。これは， $T_{8}$ 以 上の延伸では非晶鎖の熱運動が活発になり，しかも延伸 張力が低いので，配向緩和が起こった結果であると考え られる6).

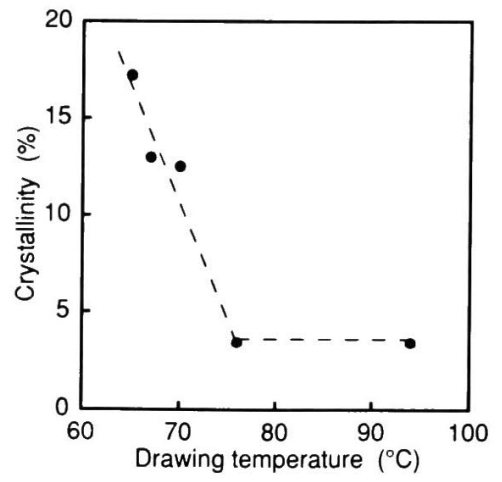

Fig. 6. Changes in the crystallinity with drawing temperature.

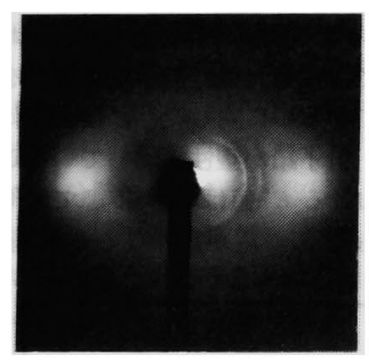

$\mathrm{Td}=65^{\circ} \mathrm{C}$

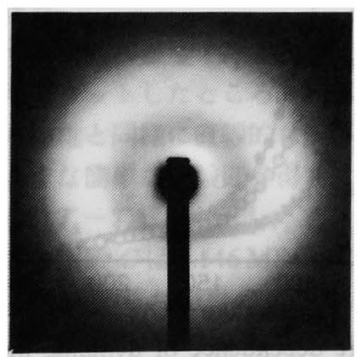

$\mathrm{Td}=90^{\circ} \mathrm{C}$

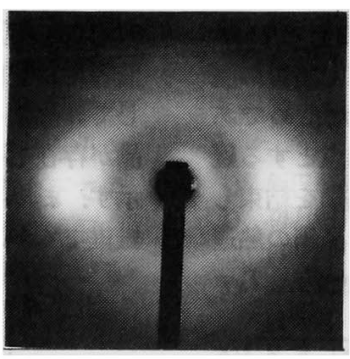

$\mathrm{Td}=67^{\circ} \mathrm{C}$

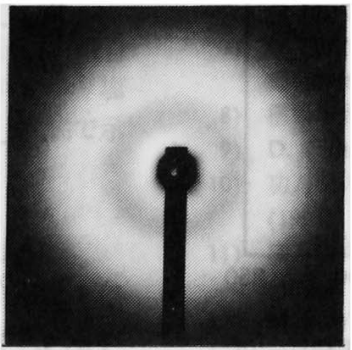

$\mathrm{Td}=94^{\circ} \mathrm{C}$

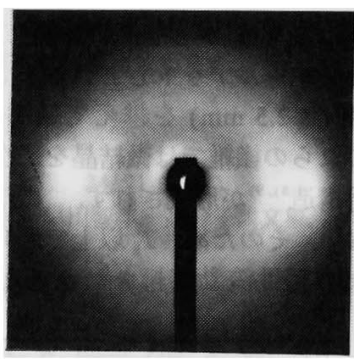

$\mathrm{Td}=70^{\circ} \mathrm{C}$

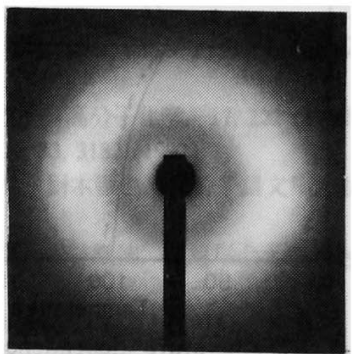

$\mathrm{Td}=102^{\circ} \mathrm{C}$

Fig. 7. Wide angle $\mathrm{X}$-ray photographs of the fibers obtained at various drawing temperatures. 
Fig. 6 に $\sigma_{\mathrm{c}}$ の下で延伸した䄉維の結晶化度 $\left(X_{\mathrm{w}}\right)$ と $T_{\mathrm{d}}$ との関係を示す． $T_{\mathrm{B}}$ 以上で延伸した繊維の $X_{\mathrm{w}}$ はいずれ も $4 \%$ 程度と低く，ほとんど非晶質である，一方， $T_{8}$ 以 下では $T_{\mathrm{d}}$ が低いほよ゙ $X_{\mathrm{w}}$ は高くなり， $T_{\mathrm{d}}=65^{\circ} \mathrm{C}$ で延伸 した綫維の $X_{\mathrm{w}}$ は $17 \%$ になる。また，配向結晶化が $T_{\mathrm{d}}$ に強く依存していることは，Fig. 7 に示す各 $T_{\mathrm{d}}$ で延伸し た繊維の広角 X 線回折写真からも明らかである． $T_{\mathrm{d}}=$ $70^{\circ} \mathrm{C}, 67^{\circ} \mathrm{C}$, および $65^{\circ} \mathrm{C}$ で延伸した䄉維には結晶性回折 が現れ、 $T_{\mathrm{d}}$ の低下に伴い結晶性回折の方位角书よび回折 角方向の搪がりは減少し, 非晶性ハローは弱くなる。一 方, $T_{\mathrm{d}}=90,94$ および $102^{\circ} \mathrm{C}$ で延伸した織維の広角 $\mathrm{X}$ 線 回折写真には非晶相に基づく八ローのみが観察され，結 晶性の回折は存在しない。

$T_{8}$ 以下の延伸では分子鎖の熱運動が凍結された状態 で大きい延伸張力が加えられるので，分子鎖の緊張・配 向が進んで分子鎖が集束し，配向結晶化が起こる．その ため, $T_{\mathrm{d}}$ が低いほどより高度に配向した微結晶が多数生 成していると考えられる。，一方， $T_{\mathrm{g}}$ 以上の延伸では分子 鎖の熱運動が活発なうえに延伸張力が小さいため, 分子 鎖の配向緩和が生じ, 配向結晶化が起きにくいと考えら れる”。

\section{3 ネッキングソーン延伸緎維の熱収縮}

Fig. 8 に種々の $T_{\mathrm{d}}$ で得られたネッキングゾーン延伸 䄉維の TMA 曲線を示す. 原織維と $T_{\mathrm{d}}=102^{\circ} \mathrm{C}$ で延伸し た織維は $T_{3}$ 付近から急激に伸長し， $100^{\circ} \mathrm{C}$ 以上で TMA 曲線はスケールアウトしている。ここは TMA 装置の測 定範囲 $( \pm 2.5 \mathrm{~mm})$ を越えて繊維が伸長したためであ る.これらの緎維では微結晶を二次的な架橋点とする疑 似網目構造8), 9)が形成されず，微結晶が非晶鎖を結束し ていない，そのため， $T_{\mathbf{b}}$ 以上で活発化した非晶鎖の熱運 動により塑性流動が起きたと考えられる．一方， $T_{\mathrm{d}}=$

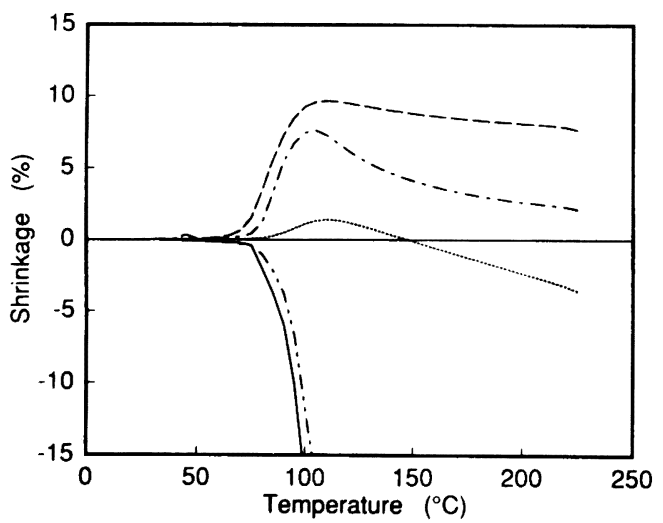

Fig. 8. Temperature dependence of shrinkage for original fiber and the fibers obtained at various drawing temperatures $\left(T_{\mathrm{d}}\right):(-)$, original; $(--), T_{\mathrm{d}}=$ $65^{\circ} \mathrm{C} ;(-\cdots), 70^{\circ} \mathrm{C} ;(\cdots \cdots), 84^{\circ} \mathrm{C} ;(-\cdots), 102^{\circ} \mathrm{C}$. $70^{\circ} \mathrm{C}$ および $65^{\circ} \mathrm{C}$ での延伸䄉維では, いずれも $T_{\mathrm{B}}$ 付近か ら熱収縮が始まり, $110^{\circ} \mathrm{C}$ 付近で最大となる。 この最大 值は， $T_{\mathrm{d}}$ が低いほど大きく， $T_{\mathrm{d}}=70^{\circ} \mathrm{C}$ の紻維では $7.6 \%$ および $T_{\mathrm{d}}=65^{\circ} \mathrm{C}$ では $9.7 \%$ である. その後, 低温結晶化 温度である $128^{\circ} \mathrm{C}^{(0)}$ 付近から配向した微結晶の成長に基 づく自発伸長がわずかに起こる゙"). Wilson は熱収縮率と IR スペクトルにおける $988 \mathrm{~cm}^{-1}$ の fold バンドとの関 係から，熱収縮は微結晶で構成された網目構造において 配向した非晶鎖が熱運動により folding したことに起因 するとしている(2).このことは, Fig. 8 の TMA 曲線にお いて $\Delta n$ の高い䄉維ほど収縮率が大きくなっていること と一致する．また，結晶性が高い場合には $X_{\mathrm{w}}$ が大きく なるほど収縮率が小さくなることが確認されている が'13)、ネッキングゾーン延伸織維では収縮率は， $X_{\mathbf{w}}$ との 間には明確な相関関係が得られず，むしろ配向の程度に 強く依存している。この結果は，ネッキングゾーン延伸 䄉維では $X_{\mathrm{w}}$ が低いため，非晶鎖の熱運動による folding を効果的に抑制できる架橋密度の高い網目構造が形成さ れていなことを示唆する。

\section{4 ネッキングソーン延伸䌯維の動的粘弾性}

Fig. 9 と 10 に $\sigma_{\mathrm{c}}$ の下で得られた延伸緎維の動的弾性 率 $\left(E^{\prime}\right)$ と損失正接 $(\tan \delta)$ の温度依存性を示す。 $E^{\prime}$-温 度曲線では, $T_{\mathrm{d}}=65^{\circ} \mathrm{C}, 70^{\circ} \mathrm{C}$, および $84^{\circ} \mathrm{C}$ で延伸した紻 維には皮革状領域が存在するのに対し, $T_{\mathrm{d}}=90^{\circ} \mathrm{C}$ と $94^{\circ} \mathrm{C}$ での延伸繊維にはこの領域は存在しない。これは, 前者では配向結晶化で生成した微結晶が網目構造を形成 して非晶鎖を拘束しているのに対し ${ }^{14)}$. 15)，後者では微結 晶が存在しないため, 分子鎖が塑性流動していることを 示す.また, $20^{\circ} \mathrm{C}$ における $E^{\prime}$ 值は $T_{\mathrm{d}}=65^{\circ} \mathrm{C}$ で延伸した 䄉維で $6.8 \mathrm{GPa}$ と最も高く， $T_{\mathrm{d}}$ が高くなると $E^{\prime}$ 値は順

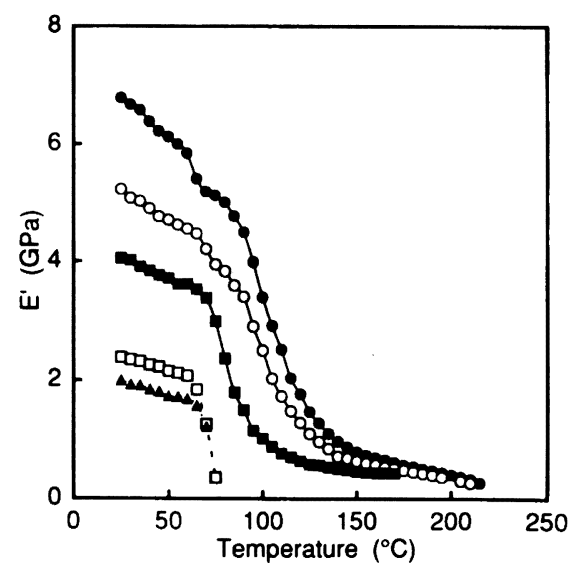

Fig. 9. Temperature dependence of dynamic modulus $\left(E^{\prime}\right)$ for the fibers obtained at various drawing temperatures $\left(T_{\mathrm{d}}\right):(\bigcirc), T_{\mathrm{d}}=65^{\circ} \mathrm{C} ;(\bigcirc), 70^{\circ} \mathrm{C} ;(\square)$, $84^{\circ} \mathrm{C}$; $\left.\square\right), 90^{\circ} \mathrm{C}$; (A), $94^{\circ} \mathrm{C}$. 


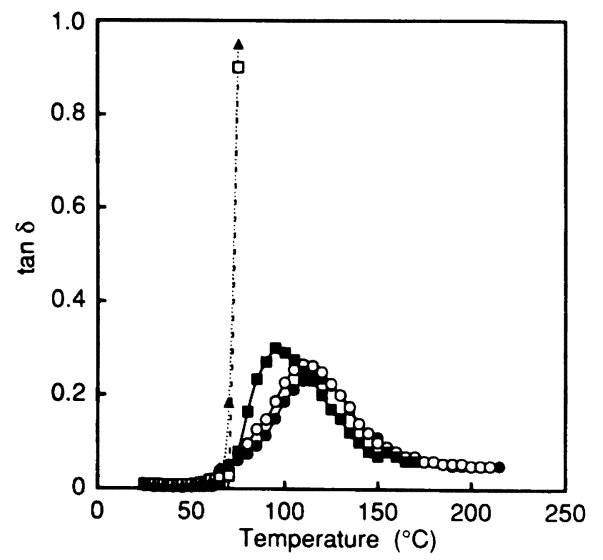

Fig. 10. Temperature dependence of loss tangent $(\tan \delta)$ for the fibers obtained at various drawing temperatures $\left(T_{\mathrm{d}}\right):(\bigcirc), T_{\mathrm{d}}=65^{\circ} \mathrm{C} ;(\bigcirc), 70^{\circ} \mathrm{C} ;(\square)$, $84^{\circ} \mathrm{C} ;(\square), 90^{\circ} \mathrm{C} ;(\Delta), 94^{\circ} \mathrm{C}$.

次低下し, $T_{\mathrm{d}}=94^{\circ} \mathrm{C}$ で延伸した䄉維の值は $2.0 \mathrm{GPa}$ と低 く, 未延伸原紻維の弾性率にほぼ等しい。

Fig. 10 に示す $\tan \delta$-温度曲線では, $T_{\mathrm{d}}=65^{\circ} \mathrm{C}, 70^{\circ} \mathrm{C}$, および $84^{\circ} \mathrm{C}$ で延伸した紻維にはガラス転移に基づく $\alpha$ 分散が $95^{\circ} \mathrm{C}$ から $115^{\circ} \mathrm{C}$ の温度範囲で観察されるが， $T_{\mathrm{d}}$ $=90^{\circ} \mathrm{C}$ と $94^{\circ} \mathrm{C}$ で延伸した織維には $\alpha$ 分散か確認されな い. $T_{\mathrm{d}}=84^{\circ} \mathrm{C}$ 以下で延伸した䄉維に観察される $\alpha$ 分散 のピーク温度は $T_{\mathrm{d}}$ が低くなると高温側にシフトし, ピーク強度は小さくなる． $T_{\mathrm{d}}=65^{\circ} \mathrm{C}$ で延伸した織維の ピーク温度は $115^{\circ} \mathrm{C}$ と最も高く, その強度は最も小さ い.この $\alpha$ 分散の変化から, 臨界ネッキング応力下での 延伸の場合, より低い $T_{\mathrm{d}}$ で延伸を行うと, 結晶性・配向 性の高い高次構造が形成され非晶鎖をより拘束している と考えられる。

\section{4 結 論}

未延伸ポリエチレンテレフタレート䄉維の延伸温度 $\left(T_{\mathrm{d}}\right)$ と臨界ネッキング応力 $\left(\sigma_{\mathrm{c}}\right)$ との関係を調べ以下の 結果を得た。

1) ガラス転移温度 $\left(T_{\mathrm{g}}=75^{\circ} \mathrm{C}\right)$ 以下で $\sigma_{\mathrm{c}}$ を $\left(T_{\mathrm{g}}-T_{\mathrm{d}}\right)$ についてプロットしたところ, PEEK フィルムやポリ塩 化ビニル䄉維と同様に直線的な関係が成立し，次式で示 されるような簡単な経験則を得た。

$$
\sigma_{\mathrm{c}}=C\left(T_{\mathrm{g}}-T_{\mathrm{d}}\right) \quad\left(\text { ただし, } T_{\mathrm{g}}>T_{\mathrm{d}}\right)
$$

なお，この定数 $C$ は $0.546 \mathrm{MPa} \cdot{ }^{\circ} \mathrm{C}^{-1}$ であった.

2） $\sigma_{\mathrm{c}}$ で延伸した織維のネッキング延伸倍率は 3 倍 から 5 倍の範囲内にあり, $T_{\mathrm{d}}$ が高いほどわずかながら大 きい. また, 複屈折は $T_{\mathrm{d}}$ の低下とともにほぼ直線的に増 加し， $T_{\mathrm{d}}=102^{\circ} \mathrm{C}$ では 0.008 と低いが, $T_{\mathrm{d}}=65^{\circ} \mathrm{C}$ では 0.150 と最も高い値を示す.
3） $T_{8}$ 以上での臨界ネッキング応力下でのゾーン延 伸では配向結晶化しない. 一方, $T_{8}$ 以下では配向結晶化 により微結晶が生じ, $T_{\mathrm{d}}$ が低いほど結晶化度及び結晶の 配向性が高い.

4) 原織維と $T_{\mathrm{d}}=102^{\circ} \mathrm{C}$ で延伸した䄉維は $T_{\mathrm{g}}$ 付近か ら急激に伸長する.一方, $T_{\mathrm{d}}=80^{\circ} \mathrm{C}, 70^{\circ} \mathrm{C}$ ，および $65^{\circ} \mathrm{C}$ で延伸した織維は $T_{\mathrm{g}}$ 付近から熱収縮し始め， $T_{\mathrm{d}}$ が低い ほど収縮率が大きい。

5) $\sigma_{\mathrm{c}}$ での延伸織維の $20^{\circ} \mathrm{C}$ における動的弾性率は延 伸温度の低下とともに增加する．また， $\tan \delta$-温度曲線 では, $T_{\mathrm{d}}=65^{\circ} \mathrm{C}, 70^{\circ} \mathrm{C}$, および $84^{\circ} \mathrm{C}$ で延伸した䄉維には ガラス転移に基づく $\alpha$ 分散が観察され， $\alpha$ 分散ピーク温 度は $T_{\mathrm{d}}$ が低くなると高温側にシフトし，そのピーク強 度はしだいに小さくなる。一方， $T_{\mathrm{d}}=90^{\circ} \mathrm{C}$ と $94^{\circ} \mathrm{C}$ で延 伸した䄉維には $\alpha$ 分散が確認されない。

以上の結果から，PEEK フィルムやポリ塩化ビ二ル䄉 維のネッキングゾーン延伸の場合と同様, 未延伸ポリ (エチレンテレフタレート) 䄉維においても $\sigma_{\mathrm{c}}$ と $\left(T_{\mathrm{g}}-\right.$ $\left.T_{\mathrm{d}}\right)$ との間には原点を通る直線関係が成立することが確 認された。 また，臨界ネッキング応力下でのゾーン延伸 では, ガラス転移温度以下で配向結晶化が起き, 延伸温 度が低いほど結晶性および配向性が高くなることが分 かった.

謝 辞 ご支援を睗わった江野科学振興財団，ならひに試料 を提供して頂いた東レ株式会社に感謝致します。

\section{文献}

1) 飯田昌造, 高分子論文集, 34, 91 (1977).

2）功刀利夫，鈴木章泰，早川智洋，高分子論文集，49, 541 (1992).

3）鈴木章泰，小林㬝子，功刀利夫，高分子論文集， 50, 205 (1993).

4) R. R. Danderg and C. W. Bunn, Proc. R. Soc., Ser. A, 226, 531 (1954).

5) V. B. Gupta, S. K. Sett, and D. D. Deorukhkar, Polym. Commun., 30, 341 (1989).

6）鈴木浩司, 日比貞夫, 中西英二, 前田松夫, 牧原政幸, 高 分子論文集, 44, 207 (1987).

7) G. LeBourvellec, L. Monnerie, and J. P. Jarry, Polymer, 27, 856 (1986).

8）植松市太郎，植松淑子，高分子化学，17，222 (1960).

9) D. R. Salem, Polymer, 33, 3182 (1992).

10）功刀利夫，鈴木章泰，對木梊也，高分子論文集， 48，703 (1991).

11）功刀利夫, 鈴木章泰, 小林数佳, 䄉維学会予稿集， S-187 (1993).

12) M. P. W. Wilson, Polymer, 15, 277 (1974).

13）跉木章泰，近藤博之，功刀利夫，高分子論文集， 50, 107 (1993).

14) J. H. Dumbleton and T. Murayama, Kolloid-Z. u. Z. Polym., 220, 41 (1967). 
15）笹野美子, 小川靖夫, 河合 徹, 絨維学会誌, 33, T-575 (1977).

\section{Relation between Drawing Temperature and Critical Necking Tension on Zone-Drawing for Poly(ethylene terephtha-} late) Fibers

Akihiro SUZUKI, Keiko KoBayashi, and Toshio KunUgI

*1 Department of Applied Chemistry and Biotechnology Faculty of Engineering, Yamanashi University (4-3-11 Takeda, Kofu, 400 Japan)

The relation between the drawing temperature $\left(T_{\mathrm{d}}\right)$ and the critical necking tension $\left(\sigma_{\mathrm{c}}\right)$ has been investigated for amorphous unoriented Poly(ethylene terephthalate) (PET) fibers. The $\sigma_{\mathrm{c}}$ was defined as the minimum tension needed to generate a necking at a given $T_{\mathrm{d}}$. The $\sigma_{\mathrm{c}}$ varied inversely with $T_{\mathrm{d}}$ in the temperature range below $T_{\mathrm{g}}: 75^{\circ} \mathrm{C}$. It was found that the temperature difference between $T_{\mathrm{g}}$ and $T_{\mathrm{d}}$ was proportional to the $\sigma_{\mathrm{c}}: \sigma_{\mathrm{c}}=C\left(T_{\mathrm{g}}-T_{\mathrm{d}}\right)$. Where $C$ has a value of $0.546 \mathrm{MPa} /{ }^{\circ} \mathrm{C}$. The birefringence and the crystallinity in the temperature range below $T_{\mathrm{g}}$ increased steadily with decreasing $T_{\mathrm{d}}$, but those in the temperature range above $T_{\mathrm{g}}$ were very low and hardly depended on $T_{\mathrm{d}}$. The fiber zone-drawn at $65^{\circ} \mathrm{C}$ has a high birefringence of 0.150 and a crystallinity of $17 \%$, respectively. However, the fiber zone-drawn at $102^{\circ} \mathrm{C}$ has a low birefringence of 0.008 and a crystallinity of $4 \%$. No strain-induced crystallization occurred at temperatures above $T_{\mathrm{g}}$. The viscoelastic behavior of the fibers zone-drawn below $T_{\mathrm{g}}$ is markedly different from that of the fibers zone-drawn above $T_{\mathrm{g}}$; the fibers obtained at the drawing temperature above $T_{\mathrm{g}}$ show no rubber-like region. The dynamic modulus increases with decreasing drawing temperature.

KEY WORDS Zone-Drawing / Poly(ethylene terephthalate) Fiber / Drawing Temperature / Necking / Critical Necking Tension / TMA Curve / Strain-Induced Crystallization / (Received April 8, 1993; Accepted May 31, 1993)

[Kobunshi Ronbunshu, 51(1), 5-10 (1994)] 